\title{
MALAYSIA'S LEGAL RESPONSE TO TACKLING THE CRIME OF ONLINE CHILD PORNOGRAPHY
}

\author{
Kirama Nasim Manbi Ushama* \\ Juriah Binti Abd. Jalil**
}

\begin{abstract}
Child pornography is not a novel crime. For many years, it has been a prevalent concern but since the availability of the internet, it has become more universal and pervasive, as cyberspace provides offenders with greater accessibility to victimize children. In response to this, numerous countries around the world, including Malaysia have implemented and enhanced regulations and policies to accord better protection to children from the crime. The aim of this paper is to highlight Malaysia's legal response and its efficacy in repressing the crime of online child pornography. Accordingly, the paper uses a doctrinal approach with content analysis to consider four issues. Firstly, the international and regional legal frameworks addressing online child pornography will be explored. Secondly, the paper provides an overview of the increasing threat of the crime in Malaysia. Subsequently, the legislative intervention taken by the nation to curb the crime is analysed, accompanied by an assessment on whether the existing law is consistent with international conventions. The overall finding reveals that the Malaysian legal mechanism has been substantially reformed to safeguard children in the country from online child pornography, especially after the enactment of the Sexual Offences Against Children Act 2017.
\end{abstract}

Keywords: child pornography, Internet, Malaysia, regulation, efficacy

* Doctoral Candidate, Ahmad Ibrahim Kulliyyah of Laws, International Islamic University Malaysia. Email: kirama82@gmail.com.

** Associate Professor, Ahmad Ibrahim Kulliyyah of Laws, International Islamic University Malaysia. Email: juriah@iium.edu.my.

[Received: 28 March 2019, Accepted: 30 September 2019, Published: 30 June 2020] 


\title{
TINDAKAN PERUNDAGAN MALAYSIA DALAM MENANGANI JENAYAH PPRNOGRAFI KANAK-KANAK DI ALAM MAYA
}

\begin{abstract}
ABSTRAK
Pornografi kanak-kanak bukanlah jenayah yang baru. Sekian lama jenayah ini telah menjadi masalah sejagat yang kini berleluasa dengan adanya internet. Kehadiran alam maya memberi ruang untuk penjenayah mencari jalan mendekati kanak-kanak untuk dijadikan mangsa. Untuk menangani masalah ini, kebanyakkan negara termasuk Malaysia telah berusaha untuk mengadakan dan meningkatkan polisi, peraturan dan undang-undang untuk melindungi kanak-kanak dari jenayah ini. Makalah ini bertujuan untuk memberi pencerahan mengenai keupayaan undang-undang di Malaysia menangani jenayah ini di alam maya. Makalah ini menggunakan pendekatan doktrin dengan analisis kandungan untuk bincangan empat isu. Pertama, perbincangan mengenai rangka undang-undang antarabangsa dan serantau dalam menangani dan membenteras jenayah ini. Kedua memberi pandangan secara menyeluruh mengenai kesan peningkatan jenayah ini ke atas kanakkanak di Malaysia. Berikutnya mengkaji undang-undang yang sedia ada and membuat analisa samada undang- undang itu adalah bersesuaian dan seragam dengan konvensyen antarabangsa. Kajian dan analisa yang dibuat mendapati bahawa undang-undang melindungi kanak kanak dari jenayah ini telah di perbaiki dengan berkesannya di Malaysia terutama selepas penubuhan Akta Kesalahan-Kesalahan Seksual Terhadap Kanak-kanak 2017.
\end{abstract}

Kata kunci: $\quad$ Pornografi kanak-kanak, Internet, Malaysia, peraturan, keberkesanan

\section{INTRODUCTION}

Child pornography is the sexual exploitation and abuse of children in pornographic materials and performances. ${ }^{1}$ The offence is a prevailing global problem and has been further enhanced with the advent of digital technologies and the internet, making it even more widespread without

United Nations Children's Fund (UNICEF), Legal Protection from Violence: Analysis of Domestic Laws Related to Violence against Children in ASEAN Member States (Bangkok: UNICEF East Asia and Pacific Regional Office (EAPRO), 2015), 142. 
any geographical limitation. ${ }^{2}$ The proliferation of mobile and digital devices, online connectivity, blogs, live streaming and online data sharing and storage facilities, have further aided in the commission of child pornography offences. ${ }^{3}$ Online child pornography is a multibillion dollar business with approximately 750,000 sexual offenders prowling the cyberspace at any given time and the sexual images of children remain in cyberspace forever, causing constant torment to the victims. $^{4}$

Child pornography websites are increasing every day and thousands of new materials are uploaded each week. Child victims range from all ages and are getting younger. The recent trend indicates a preference for pre-verbal children (babies and toddlers) as they cannot report the abuse and the materials are becoming more abhorrent, portraying children in extremely demeaning and brutal sexual activities. ${ }^{5}$ Apart from using peer-to-peer and social media networks to engage in child pornographic activities, an emerging trend also indicates that the 'Darknet' ${ }^{6}$ is increasingly used to produce and distribute child pornography materials in which one website alone can have millions of registered members. ${ }^{7}$

2 UNICEF, Child Safety Online: Global Challenges and Strategies (Florence: UNICEF Innocenti Research Centre, 2012), 13.

3 Deanna Davy, Regional Overview: Sexual Exploitation of Children in Southeast Asia (Bangkok: End Child Prostitution, Child Pornography, and the Trafficking of Children for Sexual Purposes (ECPAT) International, 2017), 35-36, accessed March 25, 2019, http://www.ecpat.org/wpcontent/uploads/2018/02/Regional-Overview_Southeast-Asia.pdf .

4 Ibid, 52; Nikoleta Lydaki Simantiri, Online Child Sexual Abuse and Exploitation: Current Forms and Good Practice for Prevention and Protection (ECPAT France and ECPAT Luxembourg, 2017), 3, accessed March 25, 2019, https://ecpat-france.fr/www.ecpat-france/wpcontent/uploads/2018/10/Revue-OCSE_ANG-min.pdf .

5 UNICEF, Legal Protection from Violence, 142.

6 It is a hidden network which can be only be accessed with specific details.

7 We Protect Global Alliance, Global Threat Assessment 2018: Working Together to End the Sexual Exploitation of Children Online (London: 2018), 9, accessed March 26, 2019, https://www.weprotect.org/; Europol, Internet Organized Crime Threat Assessment 2017 (The Netherlands: Europol, 2017), 35-36, accessed March 26, 2019, https://doi.org/10.2813/55735. 
As the scope and character of the crime evolve with technology, ${ }^{8}$ it is extremely essential to take legal measures to counter the crime. A number of international and regional instruments, such as the United Nations Convention on the Rights of the Child (CRC), ${ }^{9}$ the Optional Protocol on the sale of children, child prostitution, and child pornography (OPSC) ${ }^{10}$ the Convention on Cybercrime (Budapest Convention $)^{11}$ and the Council of Europe Convention on the Protection of Children against Sexual Exploitation and Sexual Abuse (Lanzarote Convention) ${ }^{12}$ have incorporated provisions criminalizing the offence of child pornography. Likewise, domestic laws integrating international benchmarks are equally important to curb the crime and in view of this, Malaysia has recently enacted legislation to tackle the crime. The central aspect of this paper examines Malaysia's national legislation in protecting children from online child pornography and its adequacy in combating the crime.

\section{INTERNATIONAL LEGAL FRAMEWORK AGAINST ONLINE CHILD PORNOGRAPHY}

Both internationally and regionally, several instruments have criminalized child pornography activities to protect children in the

8 Davy, Regional Overview, 52-53; We Protect Global Alliance, Global Threat Assessment 2018, 5.

9 "Convention on the Rights of the Child," opened for signature November 20, 1989, United Nations Treaty Series vol. 1577, p.3, accessed March 25, 2019, https://treaties.un.org/pages/ViewDetails.aspx?src=IND\&mtdsg_no=IV$11 \&$ chapter $=4 \&$ lang=en .

10 "Optional Protocol to the Convention on the Rights of the Child on the Sale of Children, Child Prostitution and Child Pornography," opened for signature May 25, 2000, United Nations Treaty Series vol. 2171, p.227, $\begin{array}{lll}\text { accessed } & \text { March 2019, }\end{array}$ https://treaties.un.org/pages/viewdetails.aspx?src=ind\&mtdsg_no=iv-11c\&chapter $=4 \&$ lang $=$ en .

11 "Convention on Cybercrime," opened for signature November 23, 2001, European Treaty Series no. 185, accessed March 26, 2019,https://www.coe.int/en/web/conventions/full-list//conventions/treaty $/ 185$.

12 "Council of Europe Convention on the Protection of Children against Sexual Exploitation and Sexual Abuse," opened for signature October 25, 2007, Council of Europe Treaty Series no. 201, accessed March 26, 2019, https://www.coe.int/en/web/conventions/full-list/-/conventions/treaty/201. 
cyber domain. The following is a review of the most important instruments.

\section{THE CRC AND THE OPSC}

The CRC is the first internationally binding agreement to specifically address child pornography by prohibiting the exploitation of children in pornographic performances and materials. ${ }^{13}$ However, the instrument neither provide a definition for child pornography nor does it contain provisions regarding criminal conducts in relation to child pornography. These details are addressed through its protocol, the OPSC, which supplements the CRC by prescribing specific conditions to eradicate the sexual abuse and exploitation of children. ${ }^{14}$ Accordingly, Article 2(c) of the OPSC describes child pornography as:

Any representation, by whatever means, of a child engaged in real or simulated explicit sexual activities or any representation of the sexual parts of a child for primarily sexual purposes.

This definition is broad and covers both online and offline child pornography. The term 'any representation by whatever means' includes a wide range of child pornographic materials that must be penalized by signatories. It covers all type of visual materials (photographs, videos, paintings, cartoons, and live online performances), non-visual representations (printed or digital texts and audio) and objects (sculptures, toys, ornaments). These materials can be distributed through any type of mediums such as magazines, books, including the internet and other information and communication technologies (ICTs). ${ }^{15}$

13 Article 34(1) (c) Convention on the Rights of the Child; Simantiri, Online Child Sexual Abuse, 50-51.

14 United Nations Office on Drugs and Crime, Study on the Effects of New Information Technologies on the Abuse and Exploitation of Children(Vienna: United Nations, 2015), 36, accessed March 26, 2019, https://www.unodc.org/documents/Cybercrime/Study_on_the_Effects.pdf.

15 Catherine Beaulieu, Strengthening Laws Addressing Child Sexual Exploitation: A Practical Guide (Bangkok: ECPAT International, 2008), 73, accessed 26 March, 2019, https://www.ecpat.org/wp- 
Thereafter, Article 3(1) (c) prescribes its signatories to make criminal all acts pertaining to child pornography, irrespective of whether they are committed domestically, transnationally or on an individual or organized basis. A wide array of child pornography acts are criminalized such as producing, distributing, disseminating, importing, exporting, offering, selling or possessing child pornographic materials for the purposes of production, distribution, dissemination, import, export, offer, or sale. As can be seen, the OPSC does not include in its prohibition, the simple possession (possessing without intention) of child pornographic materials, but the Committee on the Rights of the Child (CRC Committee) has nevertheless recommended that countries prohibit such conduct. While countries are not bound by this recommendation, criminalization of such an act is regarded as best practice and should, therefore, be implemented promptly. ${ }^{16}$

The OPSC also requires signatories to consider the gravity of the crime thereby implementing appropriate punishment for such acts and further forbids any attempt, complicity or participation in these crimes. ${ }^{17}$

\section{BUDAPEST AND LANZAROTE CONVENTIONS}

Articles 9 and 20 of the Budapest and Lanzarote Conventions, respectively, stipulate the criminalization of child pornography offences. Both are European treaties containing similar provisions in relation to crime. The Budapest Convention is one of the first international legal mechanisms to focus specifically on online child

content/uploads/legacy/Legal_Instrument_En_Final.pdf; Susanna Greijer and Jaap Doek, Terminology Guidelines for the Protection of Children from Sexual Exploitation and Sexual Abuse (ECPAT International and ECPAT Luxembourg, 2016), 36.

${ }^{16}$ UNICEF, Handbook on the Optional Protocol on the Sale of Children, Child Prostitution and Child Pornography

(Florence: UNICEF Innocenti Research Centre, 2009), 12; UNICEF, Regulation of Child Online Sexual Abuse: Legal Analysis of International Law and Comparative Legal Analysis, (UNICEF, 2016), 13, accessed March 26, 2019, https://www.unicef.org/namibia/na.COP_Legal_Analysis.pdf.

17 Article 3(2) and (3). 
pornography and categorizes it as content related offences. ${ }^{18}$ It refers to child pornography as pornographic materials that do not only visually represent a child engaged in sexually explicit acts, but also a person who looks like a child or realistic images like a child engaged in sexually explicit acts. ${ }^{19}$

On the other hand, the Lanzarote Convention states that any material that visually depicts a child engaged in real or simulated sexually explicit behaviour or any depiction of the sexual organs of a child for primarily sexual purposes is child pornography. ${ }^{20}$ Both of these statutory provisions exclude materials that have an artistic, medical, scientific merit or materials that have no sexual purpose, from being considered pornographic. ${ }^{21}$

What amounts to sexually explicit behaviour or act is provided in the Explanatory Reports of both Conventions, which include sexual intercourse (it can be genital-genital, oral-genital, anal-genital or oralanal intercourse between children or between an adult and a child of the same or opposite sex), bestiality, masturbation, sadistic or masochistic sexual abuse, and lascivious exhibition of the genitals or the pubic area of a child. ${ }^{22}$

Compared to the OPSC, the provisions in Budapest and Lanzorote Conventions are somewhat restricted as they expressly refer to visual representations of child pornography, thus excluding its application to representations of audio or text. ${ }^{23}$ At the same time, the definition is extended to cover the prohibition of simulated representations of children such as digitally created materials and virtual child

18 Janice Kim Song, Protecting Children from Cybercrime: Legislative Responses in Asia to Fight Child Pornography, Online Grooming, and Cyberbullying (Washington: The World Bank, 2015), 7, accessed 26 March, 2019, https://www.icmec.org/cybercrime-legislative-responses-in-asia/.

19 Article 9(2).

20 Article 20(2).

${ }^{21}$ Explanatory Report to the Budapest Convention, para 99: Explanatory Report to the Lanzarote Convention, para 142.

${ }^{22}$ Explanatory Report to the Budapest Convention, para 100; Explanatory Report to the Lanzarote Convention, para 143.

${ }^{23}$ UNICEF, Regulation of Child Online Sexual Abuse, 15-16;Greijer and Doek, Terminology Guidelines, 36-37. 
pornography. ${ }^{24}$ This is reflected in both the instruments whereby the Budapest Convention expressly prohibits virtual pornography and pornography depicting a person who is made to appear like a minor, ${ }^{25}$ while the Lanzarote Convention gives the Member States the option of forbidding the penalization of 'simulated representations or realistic images of a non-existent child. ${ }^{26}$

With regard to the criminalization of child pornography, the Budapest Convention specifically refers to the conducts forbidden in the OPSC committed via computer systems such as the production, offering or making available, distributing or transmitting, procurement, and possession of child pornography and, in addition, criminalizes the mere possession of child pornography. ${ }^{27}$

The Lanzarote Convention is mostly in line with the Budapest Convention, as it also stipulates provisions to protect children from online sexual exploitation and abuse. ${ }^{28}$ At the same time, it is even more comprehensive as it does not restrict itself to applying its provisions solely to the commission of child pornography activities via computer networks, but in general, penalizes all activities related to child pornography. Besides prohibiting the mere possession of child pornography, it further interdicts the offence of knowingly viewing or accessing child pornography via ICTs (without downloading such as live streaming). ${ }^{29}$ Like the OPSC, both the conventions emphasize on giving effective and proportionate penalties for the crime $^{30}$ and criminalize attempting, aiding, and abetting the offences. ${ }^{31}$

An important element that is an obstacle to combating child pornography effectively is the absence of a duty to report such activities. Although the society as a whole must have a duty of care to protect children from such crimes, many countries have imposed

${ }^{24}$ See Explanatory Report to the Budapest Convention, para 101; Explanatory Report to the Lanzarote Convention, para 144; Greijer and Doek, Terminology Guidelines, 36-37.

25 Article 9(2).

26 Article 20(3).

27 Article 9(1).

28 Article 20(1).

${ }^{29}$ UNICEF, Regulation of Child Online Sexual Abuse, 16; Greijer and Doek, Terminology Guidelines, 37.

${ }^{30}$ Budapest Convention, Article 13; Lanzarote Convention, Article 27.

${ }^{31}$ Budapest Convention, Article 11; Lanzarote Convention, Article 24. 
mandatory reporting duty to certain groups of individuals regarding these offences. ${ }^{32}$ These individuals can be any professionals whose work deals with children or those who come across child pornographic materials as a result of their job. Such person or offices include teachers, health care employees, and social service workers, Internet Service Providers (ISPs), or any financial organizations.

Mandatory reporting is the obligation to report suspected child pornography activities to the law enforcement agencies or to some other relevant authority, which provides an avenue for law enforcement officers to not only tackle the crime but also helps to minimize the demand for child pornography. ${ }^{33}$

The Lanzarote Convention allows professionals working in close contact with children to report to the child protection services if they reasonably believe that a child is the victim of sexual exploitation or sexual abuse. ${ }^{34}$ Such professionals do not have to worry about violating confidentiality rules, but it also does not impose a duty upon them. Likewise, anyone who is aware or thinks that a child is being sexually exploited or abused can also report to the relevant authorities. ${ }^{35}$ However, this is only a voluntary requirement.

\section{OTHER RELATED INTERNATIONAL INSTRUMENTS}

Among the international instruments which prohibits child pornography is the Convention concerning the Prohibition and Immediate Action for the Elimination of the Worst Forms of Child Labour (ILO Convention No. 182). ${ }^{36}$ This instrument mandates its Member States to take immediate and effective measures to outlaw the

${ }^{32}$ See International Centre for Missing \& Exploited Children (ICMEC), Child Pornography: Model Legislation and Global Review (Virginia: ICMEC, 2016), 5, accessed March 26, 2019, https://www.icmec.org/childpornography-model-legislation-report/.

33 Ibid; UNICEF, Legal Protection from Violence, 149.

${ }^{34}$ Article 12(1).

35 Article 12(2).

36 "Convention concerning the Prohibition and Immediate Action for the Elimination of the Worst Forms of Child Labour," adopted on June 17, 1999, no 182, accessed March 26, 2019, https://www.ilo.org/dyn/normlex/en/f?p=NORMLEXPUB:12100:0::NO::P 12100_ILO_CODE:C182. 
use, procurement or offering of a child for the production of pornography or for pornographic performances. ${ }^{37}$ However, this Convention merely prohibits the production of child pornography and does not penalize other activities related to child pornography. It also fails to elaborate on the definition of child pornography. ${ }^{38}$

Another important instrument is the Protocol to Prevent, Suppress and Punish Trafficking in Persons, Especially Women and Children (Trafficking Protocol) supplementing the United Nations Convention against Transnational Organized Crime. ${ }^{39}$ Although it does not expressly address child pornography, it is linked to the crime as it criminalizes the trafficking of children for the purpose of sexual exploitation. ${ }^{40}$

All the international instruments mentioned above may not interdict certain acts or materials related to child pornography as such crimes did not exist during the drafting of the document or were drafted to address the crime regionally. Nevertheless, taken collectively, the benchmarks stipulated in the OPSC, the Budapest Convention and the Lanzarote Convention are sufficiently broad to protect children from online sexual exploitation as they complement each other by providing a coordinated approach to combating the crime. ${ }^{41}$ Accordingly, these benchmarks will be utilized to gauge the efficiency of Malaysian law on online child pornography.

37 Articles 1 and 3(b).

38 UNICEF, Regulation of Child Online Sexual Abuse, 13.

39 "Protocol to Prevent, Suppress and Punish Trafficking in Persons Especially Women and Children, supplementing the United Nations Convention against Transnational Organized Crime," adopted on November 15, 2000 , United Nations Treaty Series, vol. 2237, p. 319, Doc. A/55/383, accessed March 26 , 2019 https://treaties.un.org/Pages/ViewDetails.aspx?src=IND\&mtdsg_no=XVIII -12 -a\&chapter $=18 \&$ lang $=$ en.

${ }^{40}$ See Article 3(a).

${ }^{41}$ UNICEF, Child Safety Online, 51. 


\section{COMBATING ONLINE CHILD PORNOGRAPHY UNDER A REGIONAL FRAMEWORK}

Malaysia is a member of many international organizations, in particular, the Association of Southeast Asian Nations (ASEAN), ${ }^{42}$ a regional legal entity established in 1967 comprising of 10 Southeast Asian countries. ${ }^{43}$ ASEAN has shown continuous efforts to collaborate regionally in tackling cross border crimes specifically in relation to the protection of women and children. Nevertheless, the focus has been mostly on combating trafficking, child sex tourism and prostitution, while child pornography has been given less importance. This is evident from the passage of numerous ASEAN Declarations and Conventions. ${ }^{44}$

Consequently, ASEAN adopted the Declaration on the Elimination of Violence against Women and the Elimination of Violence against Children in 2013. Although this Declaration does not specifically advocate for the elimination of child pornography per se, it is nevertheless a significant regional instrument in relation to child pornography because it acknowledges and seeks to prevent and protect children from all types of violence, abuse, and exploitation in all settings and, in particular, among others from sexual exploitation and cyber pornography. ${ }^{45}$ To attain this goal, ASEAN countries have

42 Malaysia is one of the co-founders of the organization.

43 "About ASEAN," Association of Southeast Asian Nations, accessed March 26, 2019, https://asean.org/asean/about-asean/.

44 Some examples are the ASEAN Declaration against Trafficking in Persons, particularly Women and Children 2004; the Declaration on the Commitments for Children in ASEAN 2001; the ASEAN Convention against Trafficking in Persons, Especially Women and Children 2015.See ECPAT International, The Commercial Sexual Exploitation of Children in East and South-East Asia: Developments, Progress, Challenges, and Recommended Strategies for Civil Society (Bangkok: ECPAT International, 2014), 42, accessed March 26, 2019, http://www.ecpat.org/wpcontent/uploads/2016/04/CSEC-Overview_SouthEastAsia.pdf; Mahidol University, Child Rights Situation Analysis within the ASEAN Region (Nakhon Pathom: Mahidol University, 2016), 14-15, accessed March 26, 2019, https://resourcecentre.savethechildren.net/library/child-rightssituation-analysis-within-asean-region.

45 See "The Declaration on the Elimination of Violence against Women and Elimination of Violence against Children in ASEAN," 2, accessed March 26, 2019, https://asean.org/?static_post=declaration-on-the-elimination-of- 
agreed to take numerous legal and non-legal measures. Specifically, they include the need to strengthen, enact or amend the national legislation on the elimination of violence against children and to combine legislation, policies, and measures to effectively investigate and prosecute the offender of such crimes. ${ }^{46}$

In order to promote the implementation of the Declaration, a Regional Plan of Action on the Elimination of Violence against Children (RPA-EVAC) was adopted in 2016, spanning 10 years from 2016 to $2025 .{ }^{47}$ This RPA-EVAC contains a set of priority actions to achieve its goal of eliminating violence and specifically accomplish target 16.2 to end abuse, exploitation, trafficking and all forms of violence and torture against children in line with the 2030 Agenda for Sustainable Development Goals adopted by the United Nations. ${ }^{48}$ Some of the key actions in relation to online child pornography include: implementing preventive measures against violence in cyberspace and reforming the legal framework to prohibit all forms of violence against children in all settings, including through the use of ICTs.

\section{THE INCREASING THREAT OF ONLINE CHILD PORNOGRAPHY IN MALAYSIA}

In recent years, Malaysia has seen exponential growth in the use of the internet and ICTs, with an equal increase in crimes committed against children via ICTs, especially the production and distribution of child

violence-against-women-in-the-asean-region-4; UNICEF, Legal Protection from Violence, 8.

46 See "The Declaration on the Elimination of Violence," 3.

47 The ASEAN Secretariat, ASEAN Regional Plan of Action on the Elimination of Violence against Children (Jakarta: The ASEAN Secretariat, 2016), 19.

48 Afrooz Kaviani Johnson and Thailand Representative to the ASEAN Commission on the Promotion and Protection of the Rights of Women and Children (ACWC), Ending Violence against Children in ASEAN Member States: Baseline Study of Priority Areas under the ASEAN Regional Plan of Action on the Elimination of Violence against Children: A Snapshot as of 2016 (Jakarta: The ASEAN Secretariat, 2017), 14, accessed March 26, 2019, https://www.unicef.org/eap/reports/ending-violence-against- childrenasean-member-states; See United Nations, "About the Sustainable Development Goals," United Nations, accessed March 26, 2019, http://www.un.org/sustainabledevelopment/sustainable-developmentgoals/; See all the priority actions in the RPA-EVAC. 
pornographic materials. ${ }^{49}$ Malaysia is recognized as one of the favourite destinations for the commission of online child pornography ${ }^{50}$ and is the third highest nation in Southeast Asia for the ownership and distribution of child pornography. ${ }^{51}$ In addition, the country has been in the newspaper headlines claiming to be one of Southeast Asia's biggest centres for the transmission of online child pornography and is also the region's No.1 consumer of child pornography. ${ }^{52}$

Malaysia has an estimated population of almost 32 million and approximately 9.4 million of the total population are children. ${ }^{53}$ The internet penetration rate is 79 per cent of the total population, 75 per cent of whom are active social media users. Mobile connectivity in the nation is higher than the total population with about 42 million connections i.e., 133 per cent of the total population, and 22 million of them use mobile device and social media, while around 24 million are mobile internet users. ${ }^{54}$

49 ECPAT International, The Commercial Sexual Exploitation of Children, 1819; UNICEF, Exploring the Digital Landscape in Malaysia: Access and Use of Digital Technologies by Children and Adolescents (Kuala Lumpur: UNICEF, 2014), 27.

${ }^{50}$ Davy, Regional Overview, 53.

${ }^{51}$ Syahirah Abdul Shukor, Hendun Abd Rahman Shah, and Nurul Atira Musa, "Regulating Children's Safety on the Internet: A Malaysian Perspective," International Journal for Studies on Children, Women, Elderly and Disabled 1 (January 2017):153, accessed March 27, 2019, http://www.ijcwed.com/wp-content/uploads/2016/12/IJCWED-38.pdf.

52 Tan Sri Lee Lam Thye, "Address Weakness to Protect our Children," New Straits Times, November 17, 2016, accessed March 27, 2019, https://www.nst.com.my/news/2016/11/189322/address-weaknessesprotect-our-children; "Malaysia No.1 Consumer of Child Porn in South-east Asia," Today World, February 1, 2018, accessed March 27, 2019, https://www.todayonline.com/world/malaysia-no-1-consumer-child-pornsouth-east-asia.

${ }^{53}$ Department of Statistics Malaysia, "Children Statistics, Malaysia, 2017,"accessed March 27, 2019, https://www.dosm.gov.my/v1/index.php?r=column/pdfPrev\&id=WGlmVn ppZ2J6b2hGZHFQMmxWQ2UwUT09.

54 "Digital, Social, and Mobile in Southeast Asia," We Are Social and Hootsuite, last updated April 18, 2018, https://aseanup.com/southeast-asiadigital-social-mobile/. 
Available data indicates that, of the 24 million Facebook users in Malaysia, 1.5 million are children aged 13-17 years and 6.6 million are from ages 18-24 years old. ${ }^{55}$ National surveys conducted with secondary school children revealed that the internet was mostly accessed for social networking purposes where there is a high likelihood of receiving sexual solicitations or being victimized on such platforms. ${ }^{56}$

According to the internet Users Survey 2017 conducted by the Malaysian Communications and Multimedia Commission (MCMC), 83.2 per cent of internet users were children aged 5 to 17 years. A whopping 93 per cent of the children had access to the internet via smart phones. The favourite activities were messaging, social networking, information gathering, and watching videos. ${ }^{57}$

The considerable amount of time children spent online and their various online interactions, makes them susceptible to various online perils, although the survey found that the parents had some control over the safety of their child on the internet. 87.1 per cent of the parents responded that they monitored their child's use of the internet, while 70.4 per cent taught their children about internet safety use..$^{58}$ However, if encountered by any cybercrime, the survey revealed that only about 18.2 per cent would lodge a complaint to the ISPs, while 8 per cent reported to authorities like the MCMC, Malaysian Computer Emergency Response Team (MyCERT), and Royal Malaysia Police $(\mathrm{PDRM}){ }^{59}$

Dangers associated with social networking are further evident from the newspaper headline like 'Hide your kids from social networks' which demonstrate the risk of sharing images of kids or babies on social media with friends and family which eventually make

55 Ibid.

56 Syahirah Abdul Shukor, Nurul Atira Musa, and Hendun Abd. Rahman Shah, "Victimisation of Children and Women on the Internet in Malaysia: A Legal Discourse," International Journal for Studies on Children, Women, Elderly and Disabled 2 (June 2017): 4, accessed March 27, 2019, http://www.ijcwed.com/wp-content/uploads/2017/06/IJCWED2_8.pdf.

57 MCMC, Internet Users Survey 2017 (Cyberjaya: MCMC, 2017), 25, accessed March 27, 2019, https://www.mcmc.gov.my/resources/statistics/internet-users-survey.

58 Ibid, 26.

59 Ibid, 24. 
their way to pornographic sites. If photos are taken with phones or devices using global positioning system (GPS), it can reveal exactly where the photos were taken, making it easy for strangers to know the location of the child. The MCMC was reported to have received 652 complaints in 2015 and 151 as of March 2016 and most of the complaints were about the spread of indecent photos and videos across all age groups including children. ${ }^{60}$

A recent incident that has jeopardized the safety of children is the report on the hacking of Facebook accounts. The hacking has affected 50 million people worldwide and if the victims have logged into other services using their Facebook accounts like Tinder or Instagram, then the hackers will also be able to access the personal data in these accounts. ${ }^{61}$ This has a potential impact not only on the privacy of children but also on their online safety as their information could be accessed by wrongdoers for exploitation or abuse purposes.

Besides the high probability of child sexual victimization provided by the statistics, surveys, and newspaper headlines, the recently reported cases on online child pornography which have come into the limelight in Malaysia, suggest that it is becoming a critical social problem and is rapidly increasing. ${ }^{62}$ For example, public outrage was caused in 2016, where a British national was arrested for pretending to be a photographer, English teacher, and philanthropist to gain access to children from disadvantaged communities. It is believed that over a period of nine years, he had abused about 200 children. Police found more than 20,000 child pornographic images in his computer and he was charged with 71 cases of sexual abuse against children aged 12 to as young as 6 months. He was convicted by the

60 June Moh, "Hide Your Kids from Social Networks," New Straits Times, June 12, 2016, accessed March 27, 2019,

https://www.nst.com.my/news/2016/06/151356/hide-your-kids-socialnetworks.

61 Rob Price, "The Facebook Hack Affecting 50 Million People Also Let the Attackers Access Users' Tinder, Spotify, and Instagram Accounts," Business Insider Malaysia, September 28, 2018, accessed March 27, 2019, https://www.businessinsider.my/facebook-hack-tinder-instagram-spotifyaccounts-2018-9/? $\mathrm{r}=\mathrm{US} \& \mathrm{IR}=\mathrm{T}$.

62 Shukor, Musa, and Shah, "Victimisation of Children," 3. 
British court to serve a prison sentence of 22 years for his sexual abuse of children and babies in Malaysia. ${ }^{63}$

There are also reports of Malaysian citizens - an engineer who was prosecuted for child pornography offences committed overseas. He was prosecuted in Singapore for sexually preying on 31 boys aged between 11-15 years. He had befriended the boys on Facebook using different names and later persuaded them to meet him. He subsequently engaged in sexual acts with the boys and recorded the activities on his mobile phone. The police found more than 2,000 video clips stored in his laptop. ${ }^{64}$

Another Malaysian who was a student in the United Kingdom was sentenced to five years' imprisonment for possessing child pornography images and videos with the intent to distribute them. The police found a life-sized mannequin of a boy and 30,000 videos and sexual images. Many of them were classified as Category A, i.e., they depicted the most extreme form of child pornographic materials. ${ }^{65}$

From the foregoing discussion, statistics, surveys, and reported cases, it appears that the threat of online child pornography in Malaysia is becoming ubiquitous. Hence, an adequate legal framework is of utmost importance in curbing the crime. The following section provides a review of Malaysia's ratification of the international frameworks, considers the definition of 'child' in the national legal framework, and examines the existing law in Malaysia that is used to prosecute offenders of child pornography.

${ }^{63}$ Karen McVeigh, "Richard Huckle Given 22 Life Sentences for Abuse of Malaysian Children," The Guardian, June 6, 2016, accessed March 27, 2019, https://www.theguardian.com/uk-news/2016/jun/06/richard-huckle-given23-life-sentences-for-abusing-malaysian-children.

64“"Paedophile Caught in Singapore," The Star Online, January 19, 2015, accessed March 27, 2019, https://www.thestar.com.my/news/nation/2015/01/19/paedophile-caughtin-spore-malaysian-engineer-pleads-guilty-to-having-sex-with-31-minors/.

${ }^{65}$ Nicholas Cheng, "Malaysian Student Jailed Over Child Porn," The Star Online, May 2, 2015, accessed March 27, 2019, https://www.thestar.com.my/news/nation/2015/05/02/msian-studentjailed-over-child-porn-scholarship-holder-had-30000-videos-and-photosshowing-extreme/. 


\section{REGULATING ONLINE CHILD PORNOGRAPHY IN MALAYSIA}

Before considering anti-child pornography laws in Malaysia, two important issues need to be considered. First, it is important to examine the nation's status as a signatory to international instruments such as the CRC and OPSC. This is because, as a signatory, Malaysia has an obligation to align its national legislation and policies with the international benchmarks to prohibit the commission of child pornography activities with rigorous punishment. ${ }^{66}$

Malaysia ratified the CRC in 1995 but has made certain reservations to the Articles that do not comply with the Constitution or to the laws and policies of the nation. ${ }^{67}$ However, some countries have been recommended by the $\mathrm{CRC}$ Committee to withdraw their reservations to the CRC, as this limits the Member States' duty to effectively address the rights and protection of children accorded by the CRC. ${ }^{68}$

In 2012, Malaysia also acceded to the OPSC and made a declaration in relation to Article 2 of the OPSC. It has stated in its declaration that 'any representation' in the definition of child pornography provided in Article 2 (c) of the OPSC shall be construed to mean 'any visual representation', which renders audio or written representation to be excluded from the definition. Although, this restriction may have a possible effect on penalizing child pornography, nevertheless, as will be further discussed, the recently enacted Sexual Offences against Children Act 2017 (Act 792) (SOCA 2017), ${ }^{69}$ does not acknowledge this limitation.

Malaysia is also a party to the UN Convention against Transnational Organized Crime, its Trafficking Protocol, and the ILO

66 Afrooz Kaviani Johnson, Mind the Gaps: A Comparative Analysis of ASEAN Legal Responses to Child Sex Tourism (Melbourne: Child Wise, 2009), 10.

67 Malaysia has expressed reservations to Articles 2, 7, 14, 28(1) (a) and 37.

68 Mahidol University, Child Rights Situation Analysis, 28; The ASEAN Secretariat, ASEAN Regional Plan of Action, 15.

69 "Sexual Offences against Children Act 2017," accessed March 27, 2019, http://www.federalgazette.agc.gov.my/outputaktap/aktaBI_20170707_WJ W008739BI.pdf.

http://www.agc.gov.my/agcportal/index.php?r=portal2/lom\&menu_id=VXl sMDlEclhJVXlGcUd6c0JreVhEUT09 . 
Convention No.182. The Budapest and Lanzarote Conventions have not been ratified by Malaysia, hence the provisions in them are not legally binding. Nonetheless, since both the Conventions contain standards pertaining to the explicit criminalization of online child pornography activities, they can be used domestically as best practice to be adopted in the enactment of child pornography legislation and policies. ${ }^{70}$ As will be discussed below, Malaysia has incorporated certain standards from these conventions into the SOCA 2017.

At the same time, taking into account the transnational nature of child pornography which requires international cooperation to effectively prosecute offenders of the crime, it would be best if the national law is harmonized and complies with these standards. ${ }^{71}$ Thus, the ratification of the Conventions can ensure the harmonization of domestic legislation as they criminalize certain offences related to child pornography that is not addressed by the OPSC. ${ }^{72}$ Since both the Conventions are open for accession by non-EU Member States, subject to unanimous consent by the signatories, ${ }^{73}$ Malaysia can follow in the footsteps of its fellow ASEAN member, the Philippines, which acceded to the Budapest Convention on 28 March 2018, becoming the first country in Southeast Asia to do so. ${ }^{74}$

Secondly, it is important to consider who is protected by an antichild pornography law. In any law criminalizing child pornography, the definition of 'child' is generally stipulated with reference to the age.

70 UNICEF, Child Safety Online, 51; UNICEF, Regulation of Child Online Sexual Abuse, 6.

${ }^{71}$ UNICEF, Regulation of Child Online Sexual Abuse, 11.

72 The offences that are not criminalized in the OPSC are the mere possession and the access and viewing of child pornography.

73 See "Chart of Signatures and Ratifications of Treaty 185," Council of Europe, accessed March 27, 2019,https://www.coe.int/en/web/conventions/full-list/-

./conventions/treaty/185/signatures?p_auth=yozk7qyT;"Chart. of Signatures and Ratifications of Treaty 201," Council of Europe, accessed March 27, 2019, http://conventions.coe.int/Treaty/Commun/ChercheSig.asp?NT=201\&CM= $\& \mathrm{DF}=\& \mathrm{CL}=\mathrm{ENG}$.

74 Argyll Cyrus Geducos, "PH Now a member of Budapest Convention n Cybercrime," Manila Bulletin, last updated March 6, 2018, https://news.mb.com.ph/2018/03/05/ph-now-a-member-of-budapestconvention-on-cybercrime/ . 
This is to identify that the law applies to a person of such age as specified in that written law. If the person is a child, then the provisions of the law will be applicable thereby protecting the child from being sexually exploited by an adult. ${ }^{75}$

The above-mentioned instruments interdicting the crime, namely the CRC, the ILO Convention No.182, and the Budapest and Lanzarote Conventions, consider a child as any person below the age of $18 .^{76}$ The OPSC does not define a child, but as it is an optional protocol to the CRC, the definition of child in the CRC would consort with the OPSC. ${ }^{77}$ Consequently, in accordance with these international instruments, any child under the age of 18 must be protected from child pornography, regardless of the age of sexual consent, which is usually lower. ${ }^{78}$ In Malaysia, SOCA 2017 is the primary legislation governing online child pornography and it complies with the international standards by prescribing the age of the child as less than 18 years old. ${ }^{79}$

\section{THE ENACTMENT OF THE SEXUAL OFFENCES AGAINST CHILDREN ACT 2017 (ACT 792)}

Before the SOCA 2017, Malaysia already had several laws to safeguard children from abuse and exploitation, as all kinds of pornography and not particularly child pornography are illegal in the country. Thus, the laws on obscenity, pornography or indecency, in general, have been used to apprehend perpetrators of child pornography. ${ }^{80}$

75 Afridah Binti Abas, "Child Abuse In Malaysia: Legal Measures for the Prevention of the Crime and Protection of the Victim," International Journal of Social Sciences and Humanity Studies 4, no.2 (2012): 2, accessed March 27, 2019, http://dergipark.gov.tr/download/article-file/257239.

${ }^{76}$ See CRC, Article 1; ILO Convention No.182, Article 2; Budapest Convention, Article 9(3); Lanzarote Convention, Article 3(a).

${ }^{77}$ UNICEF, Regulation of Child Online Sexual Abuse, 12.

${ }^{78}$ Kim Song, Protecting Children from Cybercrime, 22.

79 Section 2.

80 Juriah Abdul Jalil, "Combating Child Pornography in Digital Era: Is Malaysian Law Adequate to Meet the Digital Challenge," Pertanika Journal of Social Science and Humanities 23 (2015): 144-145, accessed March 27, 2019 , http://www.pertanika.upm.edu.my/Pertanika\%20PAPERS/JSSH\%20Vol.\% 2023\%20(S)\%20Oct.\%202015/11\%20JSSH\%20Vol\%2023\%20(S)\%20Oct 
These existing legislations are the Child Act 2001 (Act 611), which prohibits the use of children in child pornography by a person who is in charge or taking care of the child, ${ }^{81}$ the Penal Code 1936 (Act 574), ${ }^{82}$ the Printing Presses and Publications Act 1984 (Act 301) ${ }^{83}$ and the Film Censorship Act 2002 (Act 620) ${ }^{84}$ prohibit obscenity in general, whereas the Communications and Multimedia Act 1998 (Act $588)^{85}$ prohibit obscenity in cyberspace. In addition, the Malaysian Communications and Multimedia Content Code was adopted under the latter law to provide guidelines for self-regulating content disseminated to the public by the communications and multimedia industry. The Code forbids, among other items, the distribution of obscene content in cyberspace, which includes child pornography. ${ }^{86}$

These laws fail to provide specific definitions of pornography or obscenity and are not coherent with international standards. In particular, the laws display one factor i.e., they do not combat child pornography whether online or offline. ${ }^{87}$

\%202015_pg137-152.pdf; UNICEF, Child Protection in the Digital Age: National Response to Online Child Sexual Abuse and Exploitation in ASEAN Member States (Bangkok: UNICEF EAPRO, 2016), 58.

81 "Child Act 2001," accessed March 27, 2019, https://www.ilo.org/dyn/natlex/natlex4.detail?p_lang=en\&p_isn=65516\&p _country=MYS\&p_count $=199$.

82 "Penal Code," accessed March 27, 2019, http://www.agc.gov.my/agcportal/uploads/files/Publications/LOM/EN/Pen al\%20Code\%20\%5BAct\%20574\%5D2.pdf.

83 "Printing Presses and Publications Act 1984," accessed March 27, 2019, http://www.moha.gov.my/images/maklumat_bahagian/PQ/Act301.pdf.

84 "Film Censorship Act 2002," accessed March 27, 2019, http://www.agc.gov.my/agcportal/uploads/files/Publications/LOM/EN/Act $\% 20620$.pdf.

85 "Communications and Multimedia Act 1998," accessed March 27, 2019, http://www.agc.gov.my/agcportal/uploads/files/Publications/LOM/EN/Act $\% 20588 . p d f$.

86 "The Malaysian Communications and Multimedia Content Code," accessed March 27, 2019, https://www.mcmc.gov.my/skmmgovmy/files/attachments/ContentCode.pd f.

${ }^{87}$ ECPAT International, The Commercial Sexual Exploitation of Children, 55; Jalil, "Combating Child Pornography," 149-150; UNICEF, Child Protection In The Digital Age, 58. 
The inadequacy of Malaysian law to deter online child pornography was examined by Juriah Abd Jalil who highlighted four problems relating to the issue in her article. Firstly, the applicable laws mentioned above do not contain a specific provision to criminalise the possession of indecent or obscene images online. Secondly, since the laws do not provide a clear definition of pornography, child pornography, obscenity or indecency, it was difficult for the laws to cover all types of pornography. Thirdly, the non-censorship policy over the internet made it easy to access pornographic materials and websites and, lastly, there was a shortage of judicial interpretation on issues relating to offensive content. Likewise, insufficient police training and the absence of an exclusive police unit to combat online pornography was also the reason for the inadequate protection given to children from pornography. ${ }^{88}$

Due to these inadequacies, there have been increasingly horrific reports of child pornography in the nation, with headlines claiming that Malaysia is a hotbed for paedophiles. ${ }^{89}$ In particular, the case of the British national who sexually abused about 200 children under the disguise of being a teacher and philanthropist. The increase in cases and the discovery that only $6 \%$ of child sex offenders were convicted for their crimes were said to be due to the gap in the current laws, its enforcement, and the absence of specific laws to apprehend child pornography perpetrators. ${ }^{90}$

There was also the problem of under-reporting of child abuse cases in Malaysia as there was scepticism about the police authorities and the legal system. Complaints about child sexual abuse were not reported due to cultural proscription or fear of being socially disgraced, especially if the offender is a family member and the misconception that an obsession with child pornography was a trivial issue. ${ }^{91}$

To address the escalation of the crime, there was a significant need to implement a specific law against cyber abuse and exploitation of

88 Shukor, Musa, and Shah, "Victimisation of Children," 4; See also Jalil, "Combating Child Pornography."

89 "Malaysia a Paedophile Hotbed," New Straits Times, November 15, 2016, accessed March 27, 2019, https://www.pressreader.com/malaysia/newstraitstimes/20161115/281668254557986.

90 Lam Thye, "Address Weakness."

91 Ibid; UNICEF, Child Protection in the Digital Age, 62; Shukor, Musa, and Shah, "Victimisation of Children,"4. 
children. This gave birth to the SOCA 2017, which addresses the lacuna in the existing laws and, also deals with the issues stated by Juriah Abd Jalil.

SOCA 2017 also indicates Malaysia's response to the RPAEVAC. Since the RPA-EVAC spans of 10 years, the priority actions to address the violence perpetrated against children have been divided into two sections to be implemented over a period of 5 years each. For the first 5 years, the focus will be on certain priority areas comprising of both preventive and protective measures. ${ }^{92} \mathrm{~A}$ baseline study of the priority areas in the ASEAN countries was conducted in 2016, which displays the numerous initiatives of Malaysia to fulfil its obligation as an ASEAN member to eradicate violence against children. ${ }^{93}$ One important priority action is to commence a legislative review to ensure that domestic law for the protection of children from any violence is aligned with international human rights standards to which ASEAN countries are signatories, such as the CRC, OPSC, and ILO Convention. ${ }^{94}$

Malaysia has thus initiated its legislative progress by adopting the SOCA 2017 which penalizes child pornography activities in line with international legal frameworks and the amendment to the Child Act 2001 through the Child (Amendment) Act 2016 (Act A1511) which imposes a heavier sanction on child sex offenders. ${ }^{95}$

In fact, Malaysia has gone one step ahead and has started to address other areas in the RPA- EVAC. One such action is to provide a child-sensitive justice system. Hence, in 2017, the government established a special court in Putrajaya to prosecute offenders charged with committing sexual offences against children. ${ }^{96}$ This is reportedly

92 See the priority areas in The ASEAN Secretariat, ASEAN Regional Plan of Action, 33-36.

93 See Johnson and ACWC, Ending Violence against Children, for all the priority areas and Malaysia actions towards it.

94 The ASEAN Secretariat, ASEAN Regional Plan of Action, 34-35; Johnson and ACWC, Ending Violence against Children, 10.

95 "Child (Amendment) Act 2016," accessed March 27, 2019, http://www.federalgazette.agc.gov.my/outputaktap/20160725_A1511_BI_ WJW006870\%20BI.pdf; See also Johnson and ACWC, Ending Violence against Children, 47.

96 Office of the Chief Registrar Federal Court of Malaysia, "Sexual Crime Court Against Children," accessed December 17, 2019, 
the first of its kind in Southeast Asia, ${ }^{97}$ which focuses on crimes penalized in the SOCA 2017. Progress is on-going for the establishment of similar courts to specifically hear sexual crimes against children in all states in Malaysia. ${ }^{98}$ Consequently, a second special court for sexual crimes against children was opened in Kuching, Sarawak. ${ }^{99}$

These special courts aim to provide an efficient and conducive hearing of cases and will also provide appropriate child-friendly facilities for the victims such as a special witness room and live video links to facilitate the child victim to give evidence in a safe environment. ${ }^{100}$ Only judges with adequate expertise and experience

http://www.kehakiman.gov.my/en/sexual-crime-court-against-children;

Yuen Meikeng, "Special Court to Hear Child Sex Abuse Cases to be Set Up in Every State," The Star Online, December 11, 2017, accessed March 27, 2019, https://www.thestar.com.my/news/nation/2017/12/11/more-muscleagainst-predators-special-court-to-hear-child-sex-abuse-cases-to-be-set-up-

97 Ibid. in-every-stat/\#xlwHe4CV0fz2tTZ8.99.

98 " Every State to Get Court for Child Sexual Abuse Cases by End-2018," Malay Mail, December 11, 2017, accessed March 27, 2019, https://www.malaymail.com/s/1530041/every-state-to-get-court-for-childsexual-abuse-cases-by-end-2018.

${ }^{99}$ Office of the Chief Registrar Federal Court of Malaysia, "Kenyataan Akhbar: Majlis Perasmian Mahkamah Jenayah Seksual Terhadap Kanakkanak, Kompleks Mahkamah Kuching," accessed December 14, 2019, http://www.kehakiman.gov.my/sites/default/files/KENYATAAN\%20AKH BAR\%20JSKK\%20KUCHING\%20\%281\%29.pdf; "Special Court for Child Sexual Crimes Launched," Borneo Post Online, April 18, 2018, accessed March 27, 2019, http://www.theborneopost.com/2018/04/18/special-courtfor-child-sexual-crimes-launched/.

${ }^{100}$ It should be mentioned here that Malaysia already had laws authorizing the use of live or recorded evidence, albeit in a normal court. For instance, Evidence of Child Witness Act 2007, section 3(1) provides various methods a child can give witness, which includes using a screen to separate the child witness and the offender, by live link or by video recording. Additionally, Criminal Procedure Code, section 272 B also permits the use of such evidence (although children are not specifically mentioned) but here the court has the capacity to decline such evidence. Therefore, the establishment of a court particularly handling child sex offenders and addressing the needs of the child victims is a good action by the country. See Lydie Pak, Vincent Wong, and Adaiana Souza Lima, Malaysia ECPAT Country Overview: A Report on the Scale, Scope and Context of the Sexual Exploitation of 
can preside over the special court, while capacity building and training will also be given to both judges and prosecutors to better handle the cases. ${ }^{101}$ Since the formation of the special court, a total of 382 cases of sexual crimes against children have been filed, of which 314 cases had been decided and 68 cases are still pending. ${ }^{102}$

Furthermore, a special handbook containing guidelines for conducting cases of sexual offences against children has also been produced. ${ }^{103}$ It is extensive and covers issues such as police reporting and investigations, trial proceedings, and the handling, protecting, and supporting of child victims and witnesses. The handbook will aid the child victims to understand the procedures involved in handling cases of sexual crimes against children, while the working committee that prepared the handbook will monitor the effective implementation of the guidelines and will update them accordingly. ${ }^{104}$

\section{ASSESSMENT OF THE SOCA 2017}

Children (Bangkok: ECPAT International,2018), 36, accessed March 27, 2019, https://www.eturbonews.com/wp-content/uploads/2018/07/ECPATCountry-Overview-Malaysia-2018.pdf.

${ }^{101}$ Johnson and ACWC, Ending Violence against Children, 51; Meikeng, "Special Court."

102 "382 Cases Filed at Special Court for Sexual Crimes Against Children," The Sun Daily, March 13, 2018, accessed March 27, 2019, https://www.thesundaily.my/archive/382-cases-filed-special-courtsexual-crimes-against-children-GUARCH532108.

103 "Garis Panduan Khas untuk Mengendalikan Kes Kesalahan Seksual terhadap Kanak-Kanak di Malaysia," Office of the Chief Registrar Federal Court of Malaysia, accessed March 27, 2019, http://www.kehakiman.gov.my/ms/pengumuman/garis-panduan-khasuntuk-mengendalikan-kes-kesalahan-seksual-terhadap-kanak-kanak-di.

${ }^{104}$ Khairah N.Karim, "Guide Book on Handling Sexual Crimes Against Children Launched," New Strait Times, December 17, 2017, accessed March 27, 2019, https://www.nst.com.my/news/nation/2017/12/314070/guidebook-handling-sexual-crimes-against-children-launched; "Special Handbook on Child Sexual Crime Cases," The Sun Daily, December 13, 2017, accessed March 2019, https://www.thesundaily.my/archive/special-handbook-child-sexual-crimecases-JUARCH511803. 
2017 is an important year for Malaysia as the nation took a dynamic action in enacting the SOCA 2017, the principal legislation that explicitly governs child pornography. Aligning itself with international benchmarks, this legislation is comprehensive covering all the key elements to safeguard children from both online and offline sexual abuse.

Firstly, in line with the OPSC, a broad definition of child pornography is set out, as any representation, wholly or in part, whether visual, audio or written, or the combination of all three, of a child or a person looking like a child engaged in sexually explicit behaviour. It also covers virtual child pornography as the definition stipulates that realistic or graphic images of a child or realistic or graphic images of a person appearing to be a child engaged in sexually explicit conduct are forbidden. The methods by which the representation can be distributed or possessed include, but are not limited to electronic, mechanical, digital, optical, or magnetic means or manually crafted or the combination of any means. ${ }^{105}$

The term 'sexually explicit conduct' is defined, following the standards set by the Budapest and Lanzarote Conventions. It includes actual or simulated sexual intercourse or lewd acts, including genitalgenital, oral-genital, anal-genital or oral-anal between persons of the same or opposite sex, bestiality, masturbation, sadistic or masochistic sexual abuse, exhibition of a child's genitals, buttocks, breast, pubic area or anus for sexual purposes, and the use of any object or instrument for lewd acts. ${ }^{106}$

Subsequently, the law follows the international benchmarks by forbidding numerous conducts related to child pornography with appropriate sanctions for effective deterrence of the crime. The sanction provided is harsh with jail terms, whipping, and fines that reflect the seriousness of the crime as proposed by the OPSC.

The making, producing, and directing the making or production of child pornography comes with stringent penalties (imprisonment not exceeding 30 years together with a whipping of not less than 6 strokes). ${ }^{107}$ Offenders who make preparation for the commission of

${ }^{105}$ Section 4(a); Pak, Wong, and Lima, Malaysia ECPAT Country Overview, 18.

${ }^{106}$ Section 4(b).

${ }^{107}$ Section 5 . 
such acts or use a child or cause a child to be used in such activities will also be punished with 10 to 20 years imprisonment accompanied by whipping. ${ }^{108}$

A catalogue of other conducts is also penalized, including among others, distributing, selling, importing, exporting, advertising, collecting, seeking, offering or making any child pornography material available in any way. All these acts are punishable with up to 15 years of imprisonment along with 3 to 5 strokes of whipping. ${ }^{109}$ Section 10 of the law further adheres to the benchmarks stipulated in the Budapest and Lanzarote Conventions by punishing those who possess or access child pornography with a prison term of not more than 5 years or a fine of not more than RM10, 000 or both. Those who abet in committing the prescribed crimes also face the same punishment as accorded to the person committing the crime. ${ }^{110}$

The Act also addresses other sexual offences such as sexual communication with a child, ${ }^{111}$ child grooming, ${ }^{112}$ and offences relating to physical and non-physical sexual assault. ${ }^{113}$

Following the spirit of the Lanzarote Convention, ${ }^{114}$ the legislation also specifically stipulates that any person who has a relationship of trust with a child will be punished for the commission of any child pornography offences stipulated in the Act. ${ }^{15}$ These persons include but are not limited to parents, guardians, coaches, public servants or professionals in the educational and healthcare environment. These persons who have care and authority over the child will not only face the penalty imposed for committing the stated crime but also an additional penalty of up to 5 years imprisonment with not less than 2 strokes of whipping. ${ }^{116}$

The SOCA 2017 also imposes a blanket obligation to report child pornography, on anyone who has the knowledge of such activities so

\footnotetext{
${ }^{108}$ Section6 and7.

${ }^{109}$ Section 8 and 9.

${ }^{110}$ Section 21.

${ }^{111}$ Section 11.

112 Section 12 and 13.

${ }^{113}$ Section 14 and 15 .

${ }^{114}$ See Article 18(1) (b) on sexual abuse.

${ }^{115}$ Pak, Wong, and Lima, Malaysia ECPAT Country Overview, 19.

${ }^{116}$ Section 16.
} 
that protection is immediately accorded to the child. Those who withhold information about the commission or the intention to commit an offence involving a child victim to the nearest police station will be liable to a fine of not more than RM 5,000. ${ }^{117}$

A similar provision is also incorporated in the Child Act 2001, which obligates parents and legal guardians of children and professionals such as physicians, social workers, and health-care workers to report child sexual abuse. ${ }^{118}$ Anyone who fails to do so will be punished with a fine not exceeding RM5,000 or to an imprisonment not exceeding 2 years or both. People who are not professionals but reasonably believe that a child is sexually abused can also give information to the authority but there is no sanction for failure to report. ${ }^{119}$

Although both the SOCA 2017 and Child Act 2001 impose a mandatory obligation, the SOCA 2017 can be said to be more comprehensive as it prescribes a duty for anyone to report and not just professionals working in a child-related environment. At the same time, the penalty for failure to report as prescribed in the Child Act 2001 appears to be heavier, with not only a maximum fine or imprisonment but also the imposition of both penalties.

Other significant issues considered by the law are the extraterritorial application of the statute conforming to Article 4(2) of the OPSC i.e., Article 22 of the Budapest Convention and Article 25 of the Lanzarote Convention as it asserts extraterritorial jurisdiction over child pornography crimes, ${ }^{120}$ adoption of corporate liability to the crime as reflected in Article 3(4) of the OPSC (Articles 12 and 26 of the Budapest and Lanzarote Conventions respectively also address the corporate responsibility for child pornography offences), ${ }^{121}$ providing rehabilitative counselling to the offender during imprisonment, ${ }^{122}$ and supervising the offender for possible recidivism for 1 to 3 years after his release from prison. ${ }^{123}$

\footnotetext{
${ }^{117}$ Section 19.

118 Section 27-29.

${ }^{119}$ Section 29A introduced by the Child (Amendment) Act 2016.

${ }^{120}$ Section 3.

${ }^{121}$ Section 23.

${ }^{122}$ Section 26.

${ }^{123}$ Section 27.
} 
In conclusion, the SOCA 2017 has not only adopted the spirit of the OPSC but also the Lanzarote and Budapest Conventions in order to tackle the crime. The sanctions imposed for the crimes are adequately stringent and differ, taking into account the severity of child pornography offences. With regard to the effectiveness in the enforcement of the law, reports show that 36 cases have been prosecuted under the Act in the 4 months since it came into force. ${ }^{124}$ This reflects an important step in Malaysia's battle against the crime.

\section{FURTHER LEGAL DEVELOPMENTS IN ENFORCING THE LAW}

Malaysia is striding forward in its pledge to curb crimes against children by its amendment to its Child Act 2001 whereby the punishment for child sexual abuse has been reviewed upward to a fine not exceeding RM50,000 from RM20,000 or a jail term for not more than 20 years from 10 years) or both. ${ }^{125}$

In addition, the amendment specifically provides for a registry that contains a criminal record of offenders convicted of sexual crimes against children. This provision allows screenings to be conducted by employers on individuals working with children. ${ }^{126}$

It should be noted that Malaysia already has a registry of people convicted of crimes in Malaysia under the Registration of Criminal and Undesirable Act 1969 (Act 7). ${ }^{127}$ However, the law is only applicable to certain offences and does not include any of the offences related to child pornography. Furthermore, the public does not have access to the information hence hindering the ability to screen potential offenders

124 "36 Cases Prosecuted under Sexual Offences against Children Act Since July," Malay Mail, November 8, 2017, accessed March 27, 2019, https://www.malaymail.com/s/1505705/36-cases-prosecuted-under-sexualoffences-against-children-act.

${ }^{125}$ Section 31(1)(b).

${ }^{126}$ UNICEF, Child Protection in the Digital Age, 21; Clarence Tan, "High Time for a Sexual Offenders Registry," Malaysia Kini, last modified February 9, 2017, https://www.malaysiakini.com/news/371856.

127 "Registration of Criminal and Undesirable Act 1969," accessed 27 March, 2019, http://www.agc.gov.my/Akta/Vol.\%201/Act\%207.pdf. 
working in a child-related environment. ${ }^{128}$ Thus, this registry can be extended to cover criminals in both cases of child sexual abuse and those convicted for child pornography offences and made more userfriendly to the public.

Nonetheless, a registry of child sex offenders is an important development in Malaysia, as the registry allows for the management of offenders so that they can be rehabilitated and avoid recidivism. ${ }^{129}$ However, there have been criticisms that the child registry is not being fully utilized by prospective employers who provide child-related services and such usage is also not mandatorily required by the legislation. ${ }^{130}$ Hence, such gaps need to be addressed by promoting awareness to employers on the significance of such checks, making it mandatory for them to check potential employees and impeding those in the registry from being employed in childrelated services. ${ }^{131}$

Another significant development is the operation of a special division to investigate sexual crimes and domestic violence committed against children and women, namely, the Sexual, Women and Child Investigation Department (also called D11) operated by the PDRM Criminal Investigation Department. ${ }^{132}$

In addition, a special taskforce, the Internet Crime against Children Investigations Unit (MICAC) has also been launched to curb

${ }^{128}$ UNICEF, Child Protection in the Digital Age, 60; Shukor, Shah, and Musa, "Regulating Children's Safety,"154.

${ }^{129}$ WePROTECT Global Alliance, Preventing and Tackling Child Sexual Exploitation and Abuse (CSEA): A Model National Response (WePROTECT Global Alliance, 2016), 13, accessed March 27, 2019, https://www.weprotect.org/the-model-national-response.

${ }^{130}$ Ida Nadirah Ibrahim, "Few Making Use of Child Registry, Rohani Says," Malay Mail, October 31, 2017, accessed March 27, 2019,https://www.malaymail.com/news/malaysia/2017/10/31/few-makinguse-of-child-registry-rohani-says/1498993; Ida Nadirah Ibrahim, "Child Registry Use Can't Be Forced, Says Rohani," Malay Mail, November 2, 2017, $\quad 27$ March, 2019, https://www.malaymail.com/news/malaysia/2017/11/02/child-registry-usecant-be-forced-says-rohani/1500571.

${ }^{131}$ Ibrahim, "Child Registry Use."

${ }^{132}$ Pak, Wong, and Lima, Malaysia ECPAT Country Overview, 26; Shukor, Musa, and Shah, "Victimisation of Children," 4. 
the online spread of sexually explicit materials relating to children. It is tasked with the duty to monitor obscene content on the internet and to investigate sexual offenders. To efficiently undertake the duty, besides collaborating with local authorities, MICAC will also exchange data with international law enforcement authorities such as Interpol and the Federal Bureau of Investigation. Moreover, it will also conduct awareness campaigns collaborating with digital companies on the digital threats inherent in cyberspace. ${ }^{133}$

This taskforce is equipped with the latest surveillance technology for internet traffic on pornographic websites including child pornography sites. Actions of users who visit these websites will be monitored and a database of these users will be formed to assist in the prosecution process. The MCMC will also assist in the process by providing the details of the said internet users. ${ }^{134}$

\section{CONCLUSION}

The preceding analysis explores Malaysia's legal response in safeguarding children in the nation from online child pornography. As internet access is high in Malaysia, so is the likelihood of children being sexually exploited or abused in the cyberspace.

Therefore, a comprehensive law is needed to give children full protection from becoming victims of the crime. The review shows that the existing framework of laws that were applicable to criminalize child pornography offences was not adequate and coherent to address the crime, proof of which is the rise in the flow of reported crimes that emerged into the limelight. This was because child pornography offences fell within general obscenity laws or child protection laws that

${ }^{133}$ Emmanuel Santa Maria Chin, "After Four Years, Police's Anti-Child Sexual Crimes Unit Officially Launched," Malay Mail, February 9, 2018, accessed March 27, 2019, https://www.malaymail.com/s/1574073/after-four-yearspolices-anti-child-sexual-crimes-unit-officially-launched; "Task Force Launched to Curb Sexual Crimes against Children Via Internet," Malaysia Kini,last modified $\quad$ February 9, 2018, https://www.malaysiakini.com/news/411754.

134 "MCMC Does Not Act On Its Own In Combating Online Pornography: Gobind Singh," The Sun Daily, July 12, 2018, accessed March 27, 2019, http://www.thesundaily.my/news/2018/07/12/mcmc-does-not-act-its-owncombating-online-pornography-gobind-singh. 
accorded limited protection for children and thus, fell short of international benchmarks. In addition, the laws relating to child pornography were scattered in various statutes and not consolidated in one statute.

To tackle the issue, Malaysia has taken many genuine legal efforts to pave the way for the fight against child pornography offences. A significant measure is the passage of the SOCA 2017, which stipulates a clear definition of child pornography and explicitly criminalizes illegal activities related to child pornography showing consistency with international legal standards. This law shows Malaysia's consideration that children are the future of the nation and its commitment to deter sexual abuses against children.

Nevertheless, one important provision that is absent from the legislation is the principles of international cooperation. As online child pornography is a cross border crime, Malaysia must oblige its duty to Article 10 of the OPSC by taking all the necessary steps to boost international cooperation in order to prevent, investigate, and prosecute the offenders of the crime. ${ }^{135}$ In conclusion, the Malaysian legal mechanism on child pornography conforms to the international benchmarks to adequately tackle the crime.

${ }^{135}$ See also Budapest Convention, Article 23; Lanzarote Convention, Article 38. 